\title{
Ativistas (Crianças) / Activist (Children)
}

https://doi.org/10.21814/uminho.ed.36.4 



\section{Ativismo Infantil}

Ativismo é um termo político relacionado com a ação direta que pretende alcançar mudanças sociais ou políticas. Seja encenado por adultos ou por crianças, o seu significado depende do contexto, receção e consciência. Refere-se ao uso de uma ação direta, mas a forma como as crianças se envolvem e funcionam como ativistas geralmente depende da dinâmica intergeracional nas sociedades, comunidades e famílias. A forma como os ativistas infantis são vistos, pode, portanto, depender se o são juntamente com os pais ou outros adultos na comunidade, ou se são ativistas enquanto parte de grupos de jovens ou movimentos sociais liderados por crianças / jovens. Neste sentido, a pesquisa demonstra que os espaços para a atividade autónoma das crianças são limitados em muitos contextos globais (também sugerido por Thomas, 2009).

Historicamente, o ativismo tem-se concentrado em questões de interesse público. Para chamar a atenção para questões invisíveis ou ocultas, como a violência doméstica e o bullying, ou para aumentar a consciencialização e a ação sobre questões que afetam a comunidade como um todo, como a paz, a resistência em conflitos ou a reconstrução após desastres ambientais ou catástrofe. 0 termo também está associado ao empoderamento. Tal inclui considerar se as crianças ou jovens têm uma palavra a dizer, se são ouvidos e autorizados / encorajados a participar na tomada de decisões e ações que afetam as suas vidas (Lundy, 2007; Johnson \& Lewin 2020).

Se as crianças, como indivíduos ou em grupos de ativistas, estão de acordo com os adultos sobre mudanças sociais e políticas, o seu ativismo pode ser apoiado e promovido como positivo. Elas podem ser vistas como promotoras em movimentos sociais e políticos mais amplos, por exemplo, no México, quando as crianças se juntaram às suas famílias para reclamarem sobre a prisão dos seus pais (Smith, 2009) ou em movimentos de jovens e ações de reconstrução após o terramoto no Nepal (Johnson \& West, 2021).

Existem, no entanto, exemplos notáveis e famosos nos quais as crianças levantaram questões que os adultos não tinham levantado, e alguns ativistas infantis famosos chamaram a atenção literalmente de todo o mundo. Historicamente, existem exemplos de jovens ativistas nos Estados Unidos. 
Depois de Martin Luther King Junior ter feito o seu famoso discurso sobre a supremacia branca e o racismo, "Eu tenho um sonho", Rosa Parks aos 15 anos recusou-se a ceder o seu lugar num autocarro no Alabama para um homem branco, facto que the valeu reconhecimento no movimento nacional de direitos civis pela igualdade racial (Wells, 2018). Dois exemplos recentes notáveis e famosos ganharam significativa atenção política e dos media: Malala, que foi baleada pelos Talibã e depois se tornou numa referência na educação de meninas, primeiro no Afeganistão e depois no mundo todo. Outro exemplo é Greta Thunberg, que chamou a atenção do mundo para as alterações climáticas e inspirou crianças internacionalmente a cumprir greves de protesto nas escolas contra as mudanças climáticas.

Em certos contextos globais, há uma história das crianças como ativistas, por exemplo, na América Latina, onde as crianças trabalhadoras fizeram manifestações e pressionaram governos sobre o seu direito ao trabalho e foram ouvidas. Como parte da recente reconcetualização dos direitos da criança (Hanson \& Nieuwenhuys, 2013, com colegas de todo o Sul e Norte global), os movimentos sociais são uma parte fundamental da concetualização da mudança. Ao realizar e traduzir os direitos da criança em acordos internacionais, os direitos de vida das crianças precisam ser entendidos como parte do processo rumo à justiça social.

O Ativismo é sobre valores e crenças. A forma como as crianças o praticam depende se estão a tentar provocar mudanças nas normas sociais, e se estão a tentar navegar pelas diferenças intergeracionais entre crenças, ou se estão a agir com e organizadas por gerações mais velhas.

Tal resulta em diferentes formas de ativismo infantil e juvenil que devem ser entendidas dentro do contexto da organização autónoma das crianças. Os adultos podem achar difícil considerar a autonomia das crianças se a mesma não se adequar às suas próprias tradições e crenças. Portanto, o apoio ao ativismo infantil varia de acordo com o contexto, a questão em causa, o apoio e diferença do público e dos seus pares.

Assume-se que o ativismo demonstra uma ação que melhora a sociedade e a cultura, mas deve haver diferenças entre as comunidades sobre o que é uma mudança desejável e digna de apoio. 0 ativismo é uma questão política na qual as crianças nem sempre são vistas como capazes de participar de forma autónoma. 
Num trabalho recente sobre públicos infantis e a vida quotidiana das crianças, Melissa Nolas e colegas da Índia e da Grécia têm-se preocupado com as experiências vividas de ativismo na vida quotidiana das crianças (por exemplo, 2016), interessando-se em compreender como as pessoas se tornam ativistas e interferem nas narrativas sobre ativismo e infância.

Também existem alguns cruzamentos entre pesquisadores relativamente às crianças como protagonistas, discutindo o modo como são fundamentais para encontrar significado nas suas realidades e guiar as pessoas através das suas histórias nas vidas quotidianas.

\section{Activist (Children)}

Activism is a political term describing direct action to achieve social or political change. Whether enacted by adults or children, its meaning depends on context, reception and awareness. As activism refers to the use of direct action, how children become involved and function as activists often depends on intergenerational dynamics in societies, communities and families. How child activists are viewed therefore may in turn depend on whether they are activists with parents or adults in communities, or whether they are activists as part of groups of young people or child/youth led social movements. In agreement with this, research has shown that spaces for children's autonomous activity are restricted across many global contexts (as also suggested by Thomas, 2009).

Historically, activism has focused on issues of public concern. Activism aims either to bring attention to invisible or hidden issues, such as domestic violence and bullying, or to raise awareness and act on issues that affect the community as a whole, such as peace, resistance in conflict or reconstruction after environmental disaster or catastrophe. The term is also associated with empowerment. This includes considering whether children or young people have a voice, are listened to, and allowed/encouraged to take part in decision-making and action that affect their lives (Lundy, 2007; Johnson \& Lewin, 2020).

If children as individuals or groups of activists are in agreement with adults on social and political change, their activism may be supported and promoted as positive. They may be seen as contributing energy to broader social and political movements. This contribution took place for example, in Mexico when children joined their families to demonstrate about their fathers being imprisoned (Smith, 2009) or in youth movements and action in 
reconstruction after the earthquake in Nepal (Johnson \& West, forthcoming 2021). There are, however, notable and famous examples of where children have raised issues that adults have not, and some individual and famous child activists have caught the attention quite literally of the whole world. Historically, there are examples of youth activists in the US. After Martin Luther King Junior made his famous "I have a dream" speech about white supremacy and racism, Rosa Parks at aged 15 years refused to give up her seat on a bus in Alabama to a white man and she was then celebrated in the national civil rights movement for racial equality (Wells, 2018). Two recent notable and famous examples have gained significant media and political attention. These are Malala who was shot by the Taliban and then became a worldwide figure for girl's education first in Afghanistan and then globally while another is Greta Thunberg who has captured the attention of the world in her warnings about climate change and inspired children internationally to form protest strikes about climate in schools.

In certain global contexts, there is a history of children acting as activists, for example in Latin America where child workers have demonstrated and lobbied governments about their rights to work and been listened to. As part of the recent reconceptualization of child rights (Hanson \& Nieuwenhuys, 2013, with colleagues from across the global south and north), social movements are a key part of conceptualizing change. In recognising and translating child rights in international agreements, the children's living rights need to be understood as part of the process towards social justice.

Activism is about values and beliefs and how children enact activism depends on whether they are trying to bring about changes to social norms and navigate intergenerational differences in beliefs or whether they are acting with and organized by older generations. This results in different forms of youth activism that have to be understood within the context of children's autonomous organization and circumstances. Adults may find children's autonomy difficult if it does not fit with their own traditions and beliefs so support for children's activism will vary with context, issues and public and peer support and difference. Activism is assumed to denote action that improves society and culture, but there are bound to be differences amongst communities about what is desirable change and worthy of support. Activism is a political issue that children are not always seen as being able to participate in autonomously.

In recent work on childhood public life and children's everyday life, Melissa Nolas and colleagues from India and Greece have been concerned about 
the lived experiences of activism in children's everyday life (for example, 2016). They concentrate on how people become connected to activism and disrupt narratives about activism and childhood.

There is also some cross-over with researchers citing children as protagonists, central in finding meaning in their lived realities and in guiding people through their stories and roles in their everyday lives.

\section{Referências / References}

Hanson, K. \& Nieuwenhuys, O. (Eds.) (2013). Reconceptualizing Children's Rights in International Development: Living Rights, Social Justice and Translations. New York: Cambridge University Press.

Johnson, V. \& Lewin, T. (2020). Learning from a Living Archive: Rejuvenating child and youth rights and participation. IDS Working Paper, Falmer: IDS.

Johnson, V. \& West, A. (Eds.) (forthcoming 2021). Youth and Positive Uncertainty: Negotiating life in post conflict and fragile environments. Warwickshire: Practical Action Publishing.

Lundy, L. (2007). 'Voice' is not enough: conceptualising Article 12 of the United Nations Convention on the Rights of the Child. British Educational Research Journal, 33(6), 927-942.

Sevasti-Nolas, M., Varvantakis, C. \& Arduldoss, V. (2016). Childhood, Activism in Everyday Life. Journal of Political and Social Psychology, 4(1), 2195-3325.

Smith, A. M. (2009). The Children of Loxicha: participation beyond the UNCRC rhetoric? In N. Thomas (Ed.), Children, Politics and Communication: Participation at the margins (pp.49-68). Bristol: Policy Press.

Wells, K. (2018). Short Introduction: Childhood Studies. Cambridge: Polity Press. 